\title{
Phytoremediation Effect on Heavy Metal Polluted Soils of Jaintia Hills in North Eastern Hill Region
}

\author{
Euwanrida Adleen Shylla Lyngdoh* and Sanjay-Swami
}

\author{
School of Natural Resource Management, College of Post Graduate Studies, (Central \\ Agricultural University-Imphal), Umiam (Barapani) - 793 103, Meghalaya, India
}

*Corresponding author

\section{Keywords}

Heavy metal pollution, Coal mined soil, Jaintia Hills, Phytoremediation, Sunflower and Asparagus

Article Info

Accepted:

12 October 2018

Available Online:

10 November 2018

\section{A B S T R A C T}

Extensive coal mining activities in Jaintia Hills of Meghalaya, has turned large areas into degraded land, creating unfavourable condition for plant growth due to heavy metal pollution. Owing mostly to existing acidity-related fertility stress, average crop productivity in acid soil regions like Meghalaya is very low, coupled with increasing concentration of heavy metals, productivity has dropped further. Therefore decontamination of these heavy metal polluted soils is very important. Phytoremediation is an aspect of bioremediation that uses plants for the treatment of polluted soils. Therefore, a pot culture experiment was conducted using heavy metal polluted coal mined soil of Jaintia Hills in order to assess the phytoremediation effect of the two crops viz. sunflower and asparagus. From the pot culture experiment, it is observed that the Sunflower was superior phytoremediating crop in comparison to Asparagus. The analysis of heavy metals in the soil after harvesting of phytoremediating crops indicated that the heavy metals content $\left(\mathrm{mg} \mathrm{kg}^{-1}\right)$ reduced significantly in both the soils phytoremediated by Sunflower and Asparagus compared with non-phytoremediated soil. However, the soil phytoremediated by Sunflower recorded least heavy metals content indicating its superiority over Asparagus.

\section{Introduction}

North-East Hill Region (NEHR) of India, comprising of Arunachal Pradesh, Manipur, Meghalaya, Mizoram, Nagaland, Sikkim and Tripura, has a total geographical area of 2.62 lakh sq km, accounted 8.0 per cent of the total area and 3.4 per cent of total cultivable area of the country. However, the region contributes only 2.8 per cent to the total food grain production of the nation. Majority of the fields in the region are situated across the hilly slopes. The sloping lands are 3-4 times less efficient than the plains in meeting the caloric and protein needs of their population.

Nearly $0.88 \mathrm{~m}$ ha area in NEHR is under Jhum cultivation. Soil health/fertility is the most crucial factor in deciding the agricultural productivity in the region. Approximately, 84 per cent of the soils in the NEHR are acidic in reaction, having low available phosphorus and zinc whereas toxicity of iron and aluminium. The toxicity of heavy metals, especially in the 
coal mine soils of the region like Meghalaya, is also a very serious issue.

Meghalaya has good deposit of subbituminous tertiary coal. The estimated reserve and production of coal in Meghalaya is 576.48 million tonnes and 5.0 million tonnes, respectively. The coals from Meghalaya possess unusual physico-chemical characteristics such as high sulphur, volatile matter and vitrinite content, and low ash content. The many environmental sensitive organic and mineral bound elements such as Fe, $\mathrm{Mg}, \mathrm{Bi}, \mathrm{Al}, \mathrm{V}, \mathrm{Cu}, \mathrm{Cd}, \mathrm{Ni}, \mathrm{Pb}$, and $\mathrm{Mn}$ etc. remain enriched in these coals. Owing mostly to acidity-related fertility stress, average crop productivity in acid soil regions like Meghalaya is very low, coupled with increasing concentration of heavy metals, productivity has dropped further. Due to extensive coal mining, large areas of Jaintia Hills of Meghalaya has been turned into degraded land, creating unfavourable condition for plant growth. In the last 12 years coal mining area has increased by $1.2 \%$ and agricultural land has decreased by $1.5 \%$ in Meghalaya due to the deposition of coal particles (Semwal et al., 2004).Sahoo (2012) reported that the average heavy metal concentration in coal mine soils of Jaintia Hills of Meghalaya was Mn (232 mg kg$\left.{ }^{-1}\right), \mathrm{Zn}$ (53.9 $\left.\mathrm{mg} \mathrm{kg}^{-1}\right), \mathrm{Cu}\left(22.9 \mathrm{mg} \mathrm{kg}^{-1}\right), \mathrm{Cr}$ (143 mg $\left.\mathrm{kg}^{-1}\right), \mathrm{Ni}\left(38.4 \mathrm{mg} \mathrm{kg}^{-1}\right), \mathrm{Pb}\left(23 \mathrm{mg} \mathrm{kg}^{-1}\right)$ and $\mathrm{Cd}\left(1.53 \mathrm{mg} \mathrm{kg}^{-1}\right)$. Subsequently, Sahoo et al., (2016) also reported that the average concentrations of trace elements varied widely: As (0.5-38.3 mg kg-1), Mn (86-3,700 $\left.\mathrm{mg} \mathrm{kg}^{-1}\right), \mathrm{Zn}\left(1.5-296 \mathrm{mg} \mathrm{kg}^{-1}\right), \mathrm{Cu}(0.5-110$ $\left.\mathrm{mg} \mathrm{kg}^{-1}\right), \mathrm{Cr}\left(17.5-954 \mathrm{mg} \mathrm{kg}^{-1}\right)$, Ni (4.3-390 $\left.\mathrm{mg} \mathrm{kg}^{-1}\right), \mathrm{Pb}\left(0.5-433 \mathrm{mg} \mathrm{kg}^{-1}\right), \mathrm{Cd}(0.02-4.48$ $\left.\mathrm{mg} \mathrm{kg}^{-1}\right)$, and $\mathrm{Hg}\left(0.02-0.69 \mathrm{mg} \mathrm{kg}^{-1}\right)$ in coal mine soils.

Although heavy metals are naturally present in the soil, geologic and anthropogenic activities increase the concentration of these elements to amounts that are harmful to both plants and animals. Some of these activities include mining and smelting of metals, burning of fossil fuels, use of fertilizers and pesticides in agriculture, production of batteries and other metal products in industries, sewage sludge, and municipal waste disposal (Alloway, 1990; Raskin et al., 1994; Shen et al., 2002; SanjaySwami and Singh, 2008a; Sanjay-Swami and Singh, 2008b). Growth reduction as a result of changes in physiological and biochemical processes in plants growing on heavy metal polluted soils has been recorded (Chatterjee and Chatterjee, 2000). Continued decline in plant growth reduces yield which eventually leads to food insecurity. Therefore, the remediation of heavy metal polluted soils cannot be overemphasized. Various methods of remediating metal polluted soils exist; they range from physical and chemical methods to biological methods. Most physical and chemical methods such as encapsulation, solidification, stabilization, electro kinetics, vitrification, vapour extraction, and soil washing and flushing are expensive and do not make the soil suitable for plant growth (Marques et al., 2009). Biological approach (bioremediation) on the other hand encourages the establishment/reestablishment of plants on polluted soils. It is an environmentally friendly approach because it is achieved via natural processes. Bioremediation is also an economical remediation technique compared with other remediation techniques. This paper discusses the nature and properties of soils polluted with heavy metals, plant growth and performance on these soils were examined. Biological approaches employed for the remediation of heavy metal polluted soils were equally highlighted in the paper.

\section{Effect of heavy metal polluted soil on plant growth}

The heavy metals that are available for plant uptake are those that are present as soluble 
components in the soil solution or those that are easily solubilized by root exudates (Blaylock and Huang, 2000). Although plants require certain heavy metals for their growth and upkeep, excessive amounts of these metals can become toxic to plants. The ability of plants to accumulate essential metals equally enables them to acquire other nonessential metals (Djingova and Kuleff, 2000). As metals cannot be broken down, when concentrations within the plant exceed optimal levels, they adversely affect the plant both directly and indirectly. Some of the direct toxic effects caused by high metal concentration include inhibition of cytoplasmic enzymes and damage to cell structures due to oxidative stress (Assche and Clijsters, 1990; Jadia and Fulekar, 2009). An example of indirect toxic effect is the replacement of essential nutrients at cation exchange sites of plants (Taiz and Zeiger, 2002).

Further, the negative influence heavy metals have on the growth and activities of soil microorganisms may also indirectly affect the growth of plants. For instance, a reduction in the number of beneficial soil microorganisms due to high metal concentration may lead to decrease in organic matter decomposition leading to a decline in soil nutrients. Enzyme activities useful for plant metabolism may also be hampered due to heavy metal interference with activities of soil micro-organisms. These toxic effects, both direct and indirect, lead to a decline in plant growth which sometimes results in the death of plant (Schaller and $\mathrm{T}$. Diez, 1991). The effect of heavy metal toxicity on the growth of plants varies according to the particular heavy metal involved in the process. It is important to note that certain plants are able to tolerate high concentration of heavy metals in their environment. Baker (1981) reported that these plants are able to tolerate heavy metals via three mechanisms, namely, (i) exclusion: restriction of metal transport and maintenance of a constant metal concentration in the shoot over a wide range of soil concentrations; (ii) inclusion: metal concentrations in the shoot reflecting those in the soil solution through a linear relationship; and (iii) bioaccumulation: accumulation of metals in the shoot and roots of plants at both low and high soil concentrations.

\section{Bioremediation of heavy metal polluted soils}

Bioremediation is the use of organisms (microorganisms and/or plants) for the treatment of polluted soils. It is a widely accepted method of soil remediation because it is perceived to occur via natural processes. It is equally a cost effective method of soil remediation. Blaylock et al., (1997) reported $50 \%$ to $65 \%$ saving when bioremediation was used for the treatment of 1 acre of $\mathrm{Pb}$ polluted soil compared with the case when a conventional method (excavation and landfill) was used for the same purpose. Although bioremediation is a no disruptive method of soil remediation, it is usually time consuming and its use for the treatment of heavy metal polluted soils is sometimes affected by the climatic and geological conditions of the site to be remediated (Schmoger et al., 2000).

Heavy metals cannot be degraded during bioremediation but can only be transformed from one organic complex or oxidation state to another. Due to a change in their oxidation state, heavy metals can be transformed to become either less toxic, easily volatilized, more water soluble (and thus can be removed through leaching), less water soluble (which allows them to precipitate and become easily removed from the environment) or less bioavailable (Garbisu and Alkorta, 1997; Garbisu and Alkorta, 2003). Bioremediation of heavy metals can be achieved via the use of microorganisms, plants, or the combination of both organisms. 
Using microbes for remediation of heavy metal polluted soils

Several microorganisms especially bacteria (Bacillussubtilis, Pseudomonas putida, and Enterobacter cloacae) have been successfully used for the reduction of $\mathrm{Cr}$ (VI) to theless toxic Cr (III) (Garbisu et al., 1998). B. subtilis has also been reported to reduce non-metallic elements. Further, $B$. cereus and $B$. thuringiensis have been shown to increase extraction of $\mathrm{Cd}$ and $\mathrm{Zn}$ from $\mathrm{Cd}$ rich soil and soil polluted with effluent from metal industry (Mohideena et al., 2010). Making the soil favourable for soil microbes is one strategy employed in bioremediation of polluted soils. This process known as biostimulation involves the addition of nutrients in the form of manure or other organic amendments which serve as $\mathrm{C}$ source for microorganisms present in the soil. The added nutrients increase the growth and activities of micro-organisms involved in the remediation process and thus this increases the efficiency of bioremediation. Although biostimulation is usually employed for the biodegradation of organic pollutants, it can equally be used for the remediation of heavy metal polluted soils. Since heavy metals cannot be biodegraded, biostimulation can indirectly enhance remediation of heavy metal polluted soil through alteration of soil $\mathrm{pH}$. It is well known that the addition of organic materials reduces the $\mathrm{pH}$ of the soil; this subsequently increases the solubility and hence bioavailability of heavy metals which can then be easily extracted from the soil.

Biochar is one organic material that is currently being exploited for its potential in the management of heavy metal polluted soils. Namgay et al., (2010) recorded a reduction in the availability of heavy metals when the polluted soil was amended with biochar; this in turn reduced plant absorption of the metals. The ability of biochar to increase soil $\mathrm{pH}$ unlike most other organic amendments
(Novak et al., 2009) may have increased sorption of these metals, thus reducing their bioavailability for plant uptake. It is important to note that, since the characteristics of biochar vary widely depending on its method of production and the feedstock used in its production, the effect different biochar amendments will have on the availability of heavy metals in soil will also differ. Further, more research is needed in order to understand the effect of biochar on soil microorganisms and how the interaction between biochar and soil microbes influences remediation of heavy metal polluted soils because such studies are rare in literature.

\section{Using plants for remediation of heavymetal polluted soils}

Phytoremediation is an aspect of bioremediation that uses plants for the treatment of polluted soils. It is suitable when the pollutants cover a wide area and when they are within the root zone of the plant. Phytoremediation of heavy metal polluted soils can be achieved via different mechanisms. These mechanisms include phytoextraction, phytostabilization, and phytovolatilization.

\section{Phytoextraction}

This is the most common form of phytoremediation. It involves accumulation of heavy metals in the roots and shoots of phytoremediation plants. These plants are later harvested and incinerated. Plants used for phytoextraction usually possess the following characteristics: rapid growth rate, high biomass, extensive root system, and ability to tolerate high amounts of heavy metals. This ability to tolerate high concentration of heavy metals by these plants may lead to metal accumulation in the harvestable part; this may be problematic through contamination of the food chain. There are two approaches to 
phytoextraction depending on the characteristics of the plants involved in the process. The first approach involves the use of natural hyper accumulators, that is, plants with very high metal-accumulating ability, while the second approach involves the use of high biomass plants whose ability to accumulate metals is induced by the use of chelates, that is, soil amendments with metal mobilizing capacity. Hyper accumulators accumulate 10 to 500 times more metals than ordinary plant; hence they are very suitable for phytoremediation. An important characteristic which makes hyper accumulation possible is the tolerance of these plants to increasing concentrations of these metals (hypertolerance). This could be a result of exclusion of these metals from the plants or by compartmentalization of these metal ions; that is, the metals are retained in the vacuolar compartments or cell walls and thus do not have access to cellular sites where vital functions such as respiration and cell division take place.

Generally, a plant can be called a hyper accumulator if it meets the following criteria: (i) the concentration of metal in the shoot must be higher than $0.1 \%$ for $\mathrm{Al}, \mathrm{As}, \mathrm{Co}, \mathrm{Cr}, \mathrm{Cu}$, $\mathrm{Ni}$, and $\mathrm{Se}$, higher than $0.01 \%$ for $\mathrm{Cd}$, and higher than $1.0 \%$ for $\mathrm{Zn}$; (ii) the ratio of shoot to root concentration must be consistently higher than 1; this indicates the capability to transport metals from roots to shoot and the existence of hyper tolerance ability; (iii) the ratio of shoot to root concentration must be higher than 1; this indicates the degree of plant metal uptake. Some of these plants include Haumania strumrobertii (Co hyperaccumulator); Aeollanthus subacaulis (Cu hyperaccumulator); Maytenus bureaviana (Mn hyperaccumulator); Minuartia verna and Agrostis tenuis ( $\mathrm{Pb}$ hyperaccumulators); Dichapeta lumgelonioides, Thlaspitatrense, and Thlaspicaerulescens (Zn hyperaccumulators); Psycotria vanhermanni and Streptanthus polygaloides (Ni hyperaccumulators); Lecythisollaria (Se hyperaccumulator). Pterisvittata is an example of a hyper accumulator that can be used for the remediation of soils polluted with As. Some plants have the ability to accumulate more than one metal. For instance, $\mathrm{Zn}$ hyper accumulator, Sedum alfredii, can equally hyper accumulates $\mathrm{Cd}$. The possibility of contaminating the food chain through the use of hyper accumulators is a major limitation in phytoextraction. However, many species of the Brassicaceae family which are known to be hyper accumulators of heavy metals contain high amounts of thiocyanates which make them unpalatable to animals; thus this reduces the availability of these metals in the food chain. Most hyper accumulators are generally slow growers with low plant biomass; this reduces the efficiency of the remediation process. Thus, in order to increase the efficiency of phytoextraction, plants with high growth rate as well as high biomass (e.g., maize, sorghum, and alfalfa) ares ometimes used together with metal chelating substances for soil remediation exercise.

\section{Phytostabilization}

Phytostabilization involves using plants to immobilize metals, thus reducing their bioavailability via erosion and leaching. It is mostly used when phytoextractionis not desirable or even possible. This form of phytoremediation is best applied when the soil is so heavily polluted so that using plants for metal extraction would take a long time to be achieved and thus would not be adequate. The growth of plants (used for phytostabilization) was adversely affected when the concentration of heavy metal in the soil was high. Phytostabilization of heavy metals takes place as a result of precipitation, sorption, metal valence reduction, or complexation. The efficiency of phytostabilization depends on the plant and soil amendment used. Plants help in 
stabilizing the soil through their root systems; thus, they prevent erosion. Plant root systems equally prevent leaching via reduction of water percolation through the soil. In addition, plants prevent man's direct contact with pollutants and they equally provide surfaces for metal precipitation and sorption. Based on the above factors, it is important that appropriate plants are selected for phytostabilization of heavy metals. Plants used for phytostabilization should have the following characteristics: dense rooting system, ability to tolerate soil conditions, ease of establishment and maintenance under field conditions, rapid growth to provide adequate ground coverage, and longevity and ability to self-propagate. Soil amendments used in phytostabilization help to inactivate heavymetals; thus, they prevent plant metal uptake and reduce biological activity. Organic materials are mostly used as soil amendments in phytostabilization. The best soil amendments are those that are easy to handle, safe to workers who apply them, easy to produce, and inexpensive and most importantly are not toxic to plants. Organic amendments are preferred because of their low cost and the other benefits they provide such as provision of nutrients for plant growth and improvement of soil physical properties. In general, phytostabilization is very useful when rapid immobilization of heavy metals is needed to prevent groundwater pollution. However, because the pollutants remain in the soil, constant monitoring of the environment is required and this may become a problem.

\section{Phytovolatilization}

In this form of phytoremediation, plants are used to take up pollutants from the soil; these pollutants are transformed into volatile forms and are subsequently transpired into the atmosphere. Phytovolatilization is mostly used for the remediation of soils polluted with $\mathrm{Hg}$. The toxic form of $\mathrm{Hg}$ (mercuric ion) is transformed into the less toxic form (elemental
$\mathrm{Hg}$ ). The problem with this process is that the new product formed, that is, elemental $\mathrm{Hg}$, may be redeposited into lakes and rivers after being recycled by precipitation; this in turn repeats the process of methyl-Hg production by anaerobic bacteria. Examples of transgenic plants which have been used for phytovolatilization of $\mathrm{Hg}$ polluted soils are Nicotianatabacum, Arabidopsis thaliana, and Liriodendron tulipifera

Combining plants and microbes for the remediation of heavy metal polluted soils

The combined use of both micro-organisms and plants for the remediation of polluted soils results in a faster and more efficient clean-up of the polluted site. Mycorrhizal fungi have been used in several remediation studies involving heavy metals and the results obtained show that mycorrhizae employ different mechanisms for the remediation of heavy metal polluted soils. For instance, while some studies have shown enhanced phytoextraction through the accumulation of heavy metals in plants, others reported enhanced phytostabilization through metal immobilization and a reduced metal concentration in plants. In general, the benefits derived from mycorrhizal associations which range from increased nutrient and water acquisition to the provision of a stable soil for plant growth and increase in plant resistance to diseases are believed to aid the survival of plants growing in polluted soils and thus help in the vegetation/revegetation of remediated soils.

\section{Materials and Methods}

In order to assess the phytoremediation effect on the heavy metals of coal mined soil of Jaintia Hills of Meghalaya, bulk surface soil sample $(0-15 \mathrm{~cm})$ was collected from heavy metal polluted soil of coal mine area of Sutnga in East Jaintia Hills (Fig. 1). 
The physico-chemical and heavy metal analysis of soil sample was estimated by using standard procedures. The soil samples exhibited $\mathrm{pH}$ 3.93, O.C. $0.83 \%$, available N, P and $\mathrm{K}$ 259.87, 9.18 and $166.00 \mathrm{~kg} \mathrm{ha}^{-1}$, respectively. The heavy metal content of the soil was recorded as $\mathrm{Cr} 95.39, \mathrm{Cd} 25.94, \mathrm{~Pb}$ 17.41, Ni 51.13 and Co $6.46 \mathrm{mg} \mathrm{kg}^{-1}$.

A pot culture experiment was conducted at Research Farm of School of Natural Resource Management, College of Post Graduate Studies in Agricultural Sciences, Central Agricultural University, Umiam, Meghalaya using processed coal mined soil with two phytoremediating crops viz. $\mathrm{C}_{1}$ Sunflower cv.
EC-68913, and $\mathrm{C}_{2}$ Asparagus cv. UPC-287 along with control $\mathrm{C}_{3}$ without phytoremediating crop and replicated 33 times.

To find out the variability in the phytoremediation effect of both the crops on the heavy metals in coal mined soil, 33 pots for each phytoremediating crop including no crop/control was considered as 33 replications and the significant means was separated by following one way ANOVA. The crop plants were harvested at 60 DAS and heavy metal concentration in the samples were estimated following standard procedures.

Fig.1 Outline map showing coal mining areas in Jaintia Hills

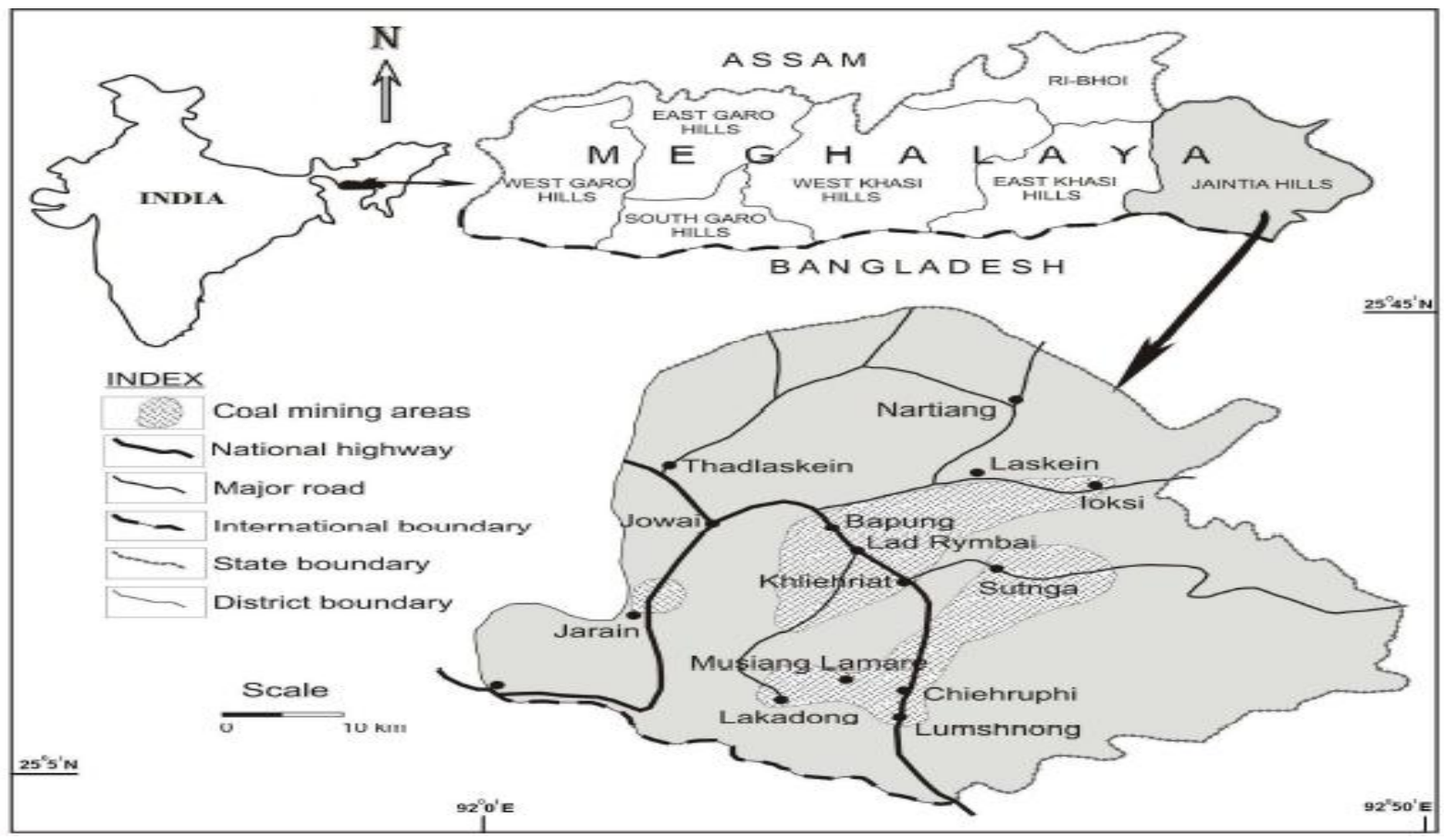

\section{Results and Discussion}

The result revealed that dry matter yield of Asparagus (11.79 $\mathrm{g} \mathrm{pot}^{-1}$ ) was higher than the Sunflower crop (5.08 $\left.\mathrm{g} \mathrm{pot}^{-1}\right)$ as shown in Table 1. However, the Sunflower was found to be superior phytoremediating crop in comparison to Asparagus as it accumulated more heavy metals (Table 2). The analysis of heavy metals in the soil after harvesting of phytoremediating crops grown in heavy metals polluted soil of coal mined area of Jaintia Hills of Meghalaya indicated that the heavy metals content $\left(\mathrm{mg} \mathrm{kg}^{-1}\right)$ reduced significantly in both the soils phytoremediated by Sunflower and Asparagus compared with 
non-phytoremediated soil Table 3. However, the soil phytoremediated by Sunflower recorded least heavy metals content indicating its superiority over Asparagus.

Plants growing on heavy metal polluted soils show a reduction in growth due to changes in their physiological and biochemical activities. This is especially true when the heavy metal involved does not play any beneficial role towards the growth and development of plants. Bioremediation can be effectively used for the treatment of heavy metal polluted soil. It is most appropriate when the remediated site is used for crop production because it is a nondisruptive method of soil remediation. Using plants for bioremediation (phytoremediation) is a more common approach to bioremediation of heavy metal compared with the use of micro-organisms.

Fig.2 Phytoremediating crops grown in heavy metals polluted soil of coal mined area of Jaintia Hills of Meghalaya

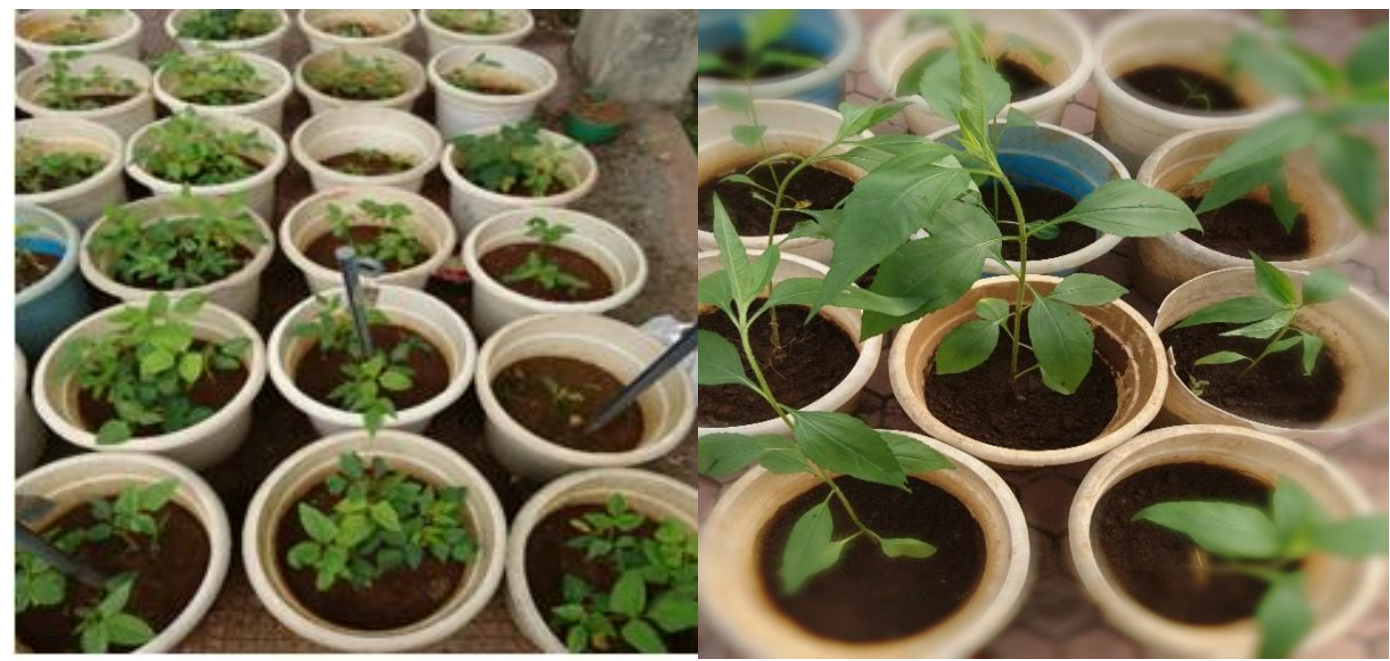

Asparagus at 30 days after sowing

Sunflower at 30 days after sowing

Table.1 Dry matter yield $\left(\mathrm{g} \mathrm{pot}^{-1}\right.$ ) of phytoremediating crops grown in heavy metals polluted soil of coal mined area of Jaintia Hills of Meghalaya

\begin{tabular}{c|c|c}
\hline Sunflower $\left(\mathbf{C}_{1}\right)$ & Asparagus $\left(\mathbf{C}_{2}\right)$ \\
\hline 5.08 & 11.79 \\
\hline
\end{tabular}

Table. 2 Heavy metals concentration $\left(\mathrm{mg} \mathrm{kg}^{-1}\right)$ and uptake $(\mathrm{mg} / \mathrm{pot})$ in phytoremediating crops grown in heavy metals polluted soil of coal mined area of Jaintia Hills of Meghalaya

\begin{tabular}{|c|l|l|l|l|l|l|l|l|l|l|} 
& Cr & Uptake & Cd & Uptake & Pb & Uptake & Ni & Uptake & Co & Uptake \\
\hline Sunflower $C_{1}$ & 10.22 & 51.83 & 2.99 & 15.05 & 2.07 & 10.40 & 6.15 & 30.88 & 1.13 & 5.68 \\
\hline SD & \pm 0.34 & \pm 1.50 & \pm 1.06 & \pm 4.08 & \pm 0.21 & \pm 0.88 & \pm 0.68 & \pm 1.20 & \pm 0.15 & \pm 0.40 \\
\hline Asparagus C & 3.67 & 42.98 & 1.22 & 14.30 & 0.78 & 9.20 & 1.83 & 21.43 & 0.35 & 4.06 \\
\hline SD & \pm 0.36 & \pm 2.37 & \pm 0.16 & \pm 1.60 & \pm 0.08 & \pm 1.07 & \pm 0.18 & \pm 1.25 & \pm 0.08 & \pm 0.85 \\
\hline
\end{tabular}


Table. 3 Heavy metals content $\left(\mathrm{mg} \mathrm{kg}^{-1}\right)$ in soil after harvesting of phytoremediating crops grown in heavy metals polluted soil of coal mined area of Jaintia Hills of Meghalaya

\begin{tabular}{|c|c|c|c|c|c|c|c|c|c|c|c|c|c|c|}
\multicolumn{4}{|c|}{$\begin{array}{c}\text { Phytoremediated by Sunflower } \\
\left(\mathbf{S}_{1}\right)\end{array}$} & \multicolumn{3}{c|}{ Phytoremediated by Asparagus } & \multicolumn{5}{|c|}{$\begin{array}{c}\text { Non-phytoremediated } \\
\left(\mathbf{S}_{2}\right)\end{array}$} \\
\hline $\mathbf{C r}$ & $\mathbf{C d}$ & $\mathbf{P b}$ & $\mathbf{N i}$ & $\mathbf{C o}$ & $\mathbf{C r}$ & $\mathbf{C d}$ & $\mathbf{P b}$ & $\mathbf{N i}$ & $\mathbf{C o}$ & $\mathbf{C r}$ & $\mathbf{C d}$ & $\mathbf{P b}$ & $\mathbf{N i}$ & $\mathbf{C o}$ \\
\hline $\mathbf{4 1 . 6 3}$ & 9.32 & 7.10 & 20.02 & 0.79 & 51.70 & 11.25 & 8.80 & 30.30 & 2.44 & 95.05 & 25.20 & 17.07 & 50.59 & 6.65 \\
\hline
\end{tabular}

Plants employ different mechanisms in the remediation of heavy metal polluted soils. Phytoextraction is the most common method of phytoremediation used for treatment of heavy metal polluted soils. It ensures the complete removal of the pollutant. Combining both plants and micro-organisms in bioremediation increases the efficiency of this method of remediation. From the pot culture experiment conducted to assess the phytoremediation effect on the heavy metals of coal mined soil of Jaintia Hills of Meghalaya, the Sunflower was found to be superior phytoremediating crop in comparison to Asparagus, hence it is recommended to the farmers of coal mined areas of Jaintia Hills of Meghalaya to phytoremediate their soil with Sunflower before planting the main crop.

\section{References}

Ajaz Haja Mohideena, R., Thirumalai Arasu, V., Narayananb, K. R. and Zahir Hussain, M. I. (2010). "Bioremediation of heavy metal contaminated soil by the exigobacterium and accumulation of $\mathrm{Cd}$, $\mathrm{Ni}, \mathrm{Zn}$ and $\mathrm{Cu}$ from soil environment" International Journal of Biological Technology, Vol. 1, No. 2: 94-101.

Alloway, B. J. (1990). Heavy Metal in Soils, John Wiley \& Sons, New York, NY, USA.

Assche, F. and Clijsters, H. (1990). "Effects of metals on enzyme activity in plants," Plant, Cell and Environment, Vol. 24: 115.

Baker, A. J. M. (1981). "Accumulators and excluders strategies in the response of plants to heavy metals," Journal of Plant Nutrition, Vol. 3: 643-654.

Blaylock, M. J. and Huang, J.W. (2000). "Phytoextraction of metals," In: Phytoremediation of Toxic Metals: Using Plants to Clean up the Environment, I. Raskin and B.D. Ensley, Eds., pp. 53-70, Wiley, New York, NY, USA.

Blaylock, M. J., Salt, D. E., Dushenkov, S. (1997). "Enhanced accumulation of $\mathrm{Pb}$ in Indian mustard by soil-applied chelating agents" Environmental Science and Technology, Vol. 31, No. 3: 860-865.

Chatterjee, J. and Chatterjee, C. (2000). "Phytotoxicity of cobalt, chromium and copper in cauliflower" Environmental Pollution, Vol. 109, No. 1: 69-74.

Djingova, R. and Kuleff, I. (2000). "Instrumental techniques for trace analysis," In: Trace Elements: Their Distribution and Effects in the Environment, J. P. Vernet, Ed., Elsevier, London, UK.

Garbisu, C. and Alkorta, I. (1997). "Bioremediation: Principles and Future," Journal of Clean Technology, Environmental Toxicology and Occupational Medicine, Vol. 6, No. 4: 351-366.

Garbisu, C. and Alkorta, I. (2003). "Basic concepts on heavy metal soil bioremediation," The European Journal of Mineral Processing and Environmental Protection, Vol. 3, No. 1: 58-66.

Garbisu, C., Alkorta, I., Llama, M. J. and Serra, J. L. (1998). "Aerobic chromate reduction by Bacillus subtilis" Biodegradation, Vol. 9, No. 2: 133-141.

Garbisu, C., Gonz'alez, S., Yang, W. H. (1995). "Physiological mechanisms regulating the 
conversion of selenite to elemental selenium by Bacillus subtilis" BioFactors, Vol. 5, No. 1: 29-37.

Jadia, C. D. and Fulekar, M. H. (2009). "Phytoremediation of heavy metals: recent techniques," African Journal of Biotechnology, Vol. 8, No. 6: 921-928.

Marques, A. P. G. C., Rangel, A. O. S. S. and Castro, P. M. L. (2009). "Remediation of heavy metal contaminated soils: Phytoremediation as a potentially promising clean-up technology" CriticalReviews in Environmental Science and Technology, Vol. 39, No. 8: 622-654.

Namgay, T., Singh, B. and Singh, B. P. (2010). "Influence of biochar application to soil on the availability of $\mathrm{As}, \mathrm{Cd}, \mathrm{Cu}, \mathrm{Pb}$, and $\mathrm{Zn}$ to maize (Zea mays L.)," Soil Research, Vol. 48, No. 6-7: 638-647.

Novak, J. M., Busscher, W. J., Laird, D. L., Ahmedna, M., Watts, D. W. and Niandou, M. A. S. (2009). "Impact of biochar amendment on fertility of a south-eastern coastal plain soil" Soil Science, Vol. 174, No. 2: 105-112.

Raskin, I., Kumar, P. B. A. N., Dushenkov, S. and Salt, D. E. (1994). "Bio-concentration of heavy metals by plants" Current Opinionin Biotechnology, Vol. 5, No. 3: 285-290.

Sahoo P.K., Tripathy, S., Equeenuddin, S. M. and Panigrahim, M.K. (2012). Geochemical characteristics of coal mine discharge vis-a-visbehavior of rare earth elements at Jaintia Hills coalfield, NorthEastern India. J. Geochem. Explor. 112: 235-243.

Sahoo, P.K., Equeenuddin, S. M. and Powell, M. A. (2016). Trace elements in soils around coal mines: Current scenario, impact and available techniques for management, Curr. Pollution Rep. 2:1-14. Sanjay-Swami and Singh, M. (2008a). Critical limits of phosphorus for durum wheat in normal and heavy metals polluted soils. Indian J. Agric. Res., 42 (4): 252-259.

Sanjay-Swami and Singh, M. (2008b). Evaluation of soil tests of available phosphorus and its critical limits for durum wheat in heavy metals polluted soils. Crop Research, 36 (1, 2 \& 3): 2332.

Schaller, A. and Diez, T. (1991). "Plant specific aspects of heavy metal uptake and comparison with quality standards for food and forage crops," In: Der Einflu $\beta$ von festenAbf"allen auf B"oden, Pflanzen, D. Sauerbeck and S. L"ubben, Eds., pp. 92-125, KFA, Julich, Germany (German).

Schmoger, M. E. V., Oven, M. and Grill, E. (2000). "Detoxification of arsenic by phytochelatins in plants," Plant Physiology, Vol. 122, No. 3: 793-801.

Semwal, D. P., Naithani, V., Pant, D. N. and Roy, P. S. (2004). Impact assessment of coal mining on landuse/ land cover using IRS-IA satellite data. [http: Ilwww. GIS.Development.coml application \geology\mineral and mining] dated 16.9.2004.

Shen, Z., Li, X., Wang, C., Chen, H. and Chua, H. (2002) "Lead phytoextraction from contaminated soil with high-biomass plant species," Journal of Environmental Quality, Vol. 31, No. 6: 1893-1900.

Taiz, L. and Zeiger, E. (2002). Plant Physiology, Sinauer Associates, Sunderland, Mass, USA.

\section{How to cite this article:}

Euwanrida Adleen Shylla Lyngdoh and Sanjay-Swami. 2018. Phytoremediation Effect on Heavy Metal Polluted Soils of Jaintia Hills in North Eastern Hill Region. Int.J.Curr.Microbiol.App.Sci. 7(11): 1734-1743. doi: https://doi.org/10.20546/ijcmas.2018.711.199 